children not registered with a local general practitioner do not fall through the net.

Arguments about services tend to be conducted without regard to the complexity of the clinical problems presented by the preschool child. Similar considerations arise with the health needs of the schoolchild. "Educational medicine," which we see as the school age branch of community paediatrics and concerned with such problems as children with reading retardation or the so called hyperactive child, needs to develop alongside a better primary care service for the schoolchild. The logic of strengthening and expanding "community paediatrics" seems to us to be inescapable.

\section{References}

${ }^{1}$ Hendrickse WA. How effective are our child health clinics? $\mathrm{Br}$ Med $\mathcal{J}$ $1982 ; 284: 575-7$.

${ }^{2}$ Office of Population Censuses and Surveys. Morbidity statistics from general practice 1971-2. London: HMSO, 1979.

${ }^{3}$ Fundundis T, Kolvin I, Gardside R. Speech retarded and deaf children: their psychological development. London: Academic Press, 1979.

${ }^{4}$ Richman N, Stevenson J, Graham P. Preschool to school: a behavioural study. London: Academic Press, 1982.

5 Bowlby J. Attachment. London: Hogarth Press, 1969.

${ }^{6}$ Bowlby J. Separation: anxiety and anger. London: Hogarth Press, 1973.

${ }^{7}$ Bowlby J. Loss: sadness and depression. London: Hogarth Press, 1981.

${ }^{8}$ Schaffer HR. The growth of sociability. Harmondsworth: Penguin Press, 1971 .
${ }^{9}$ Klaus M, Jerauld R, Kreper N, McAlpine W, Steffa M, Kennell J. Maternal attachment: importance of the first post partum days. $N$ Engl f Med $1972 ; 286: 460-3$.

1" Haggerty R. Life stress: illness and social supports. Dev Med Child Neurol 1980;22:391-400.

${ }^{11}$ Brown G, Harris T. Social origins of depression. London: Tavistock Publications, 1978.

${ }^{12}$ Moss P, Plewis I. Mental distress in mothers of pre-school children in inner London. Psychol Med 1977;7:641-52.

${ }^{13} \mathrm{Bax}$ M, Hart H. Health needs of preschool children. Arch Dis Child $1976 ; 51: 848-52$.

14 Jenkins S, Bax M, Hart H. Behaviour problems in pre-school children. f Child Psychol Psychiatry 1980;21:5-17.

${ }^{15}$ Hart H, Bax M, Jenkins S. The value of a developmental history. Dev Med Child Neurol $1978 ; 20: 442-52$.

${ }^{16}$ Hart H, Bax M, Jenkins S. The use of the child health clinic. Arch Dis Child $1981 ; 56: 440-5$.

17 Leeder SR, Corkhill R, Irwig LM, Holland WW, Colley JRT. Influence of family factors on the incidence of lower respiratory illness during the first year of life. Br F Prev Soc Med 1976;30:203-12.

${ }^{18} \mathrm{Bax} \mathrm{M}$, Hart H, Jenkins S. Assessment of speech and language development in the young child. Pediatrics 1980;66:350-4.

19 Anonymous. Community medicine conference. $\mathrm{Br}$ Med f $1982 ; 285$ :82.

${ }^{20}$ Whitmore K, Bax M, Tyrrell S. Clinical medical officers in a child health service. Br Med f 1979; :242-5.

${ }^{21}$ Kohler L. Social pediatrics in Europe. Gothenburg: Nordic School of Public Health, 1982.

${ }^{22}$ Department of Health and Social Security. Inequalities in health. London: HMSO, 1980. (Black report.)

(Accepted 16 March 1983)

\title{
Thirty years on: examination performance and career success of the 1950-1 intake of Cambridge medical students
}

\author{
RICHARD WAKEFORD, SARAH ROBERTS
}

\begin{abstract}
The relation between preclinical tripos and clinical examination results and subsequent career success of 188 medical graduates of Cambridge University was measured using five indicators of success. A generally positive relation was found, but this was not specific enough to make accurate individual predictions. Present levels of appointment were more closely related to clinical than preclinical results. No support was found for the local assertion that " $2.1 \mathrm{~s}$ " do better than "firsts" in clinical medicine. Since undergraduate examination results seem to be inaccurate predictors of later performance they should not be used as the principal evidence in making selection decisions.
\end{abstract}

\section{Introduction}

Undergraduate examination results figure prominently in subsequent job selection procedures, and it is generally tacitly assumed that there is a positive correlation between examination performance, medical competence, and career success. Unfortunately, recent reports on medical education offer little to support or contradict such a view. Those follow up studies that have been conducted largely concern the subject of specialty choice $^{12}$ or location of practice, ${ }^{34}$ sometimes in respect of a particular group of graduates (for example, women). ${ }^{5}$ Some reports are limited to the relation in performance within medical school between preclinical and clinical examination success. $^{6}$ 7 One study followed up the careers of a particular group of scholars but did not contrast them with those of other students. ${ }^{8}$

Two reports in the United Kingdom related overall success during the undergraduate course to early postgraduate experience. One reported a close association between student success and the ability to obtain subsequent posts in teaching hospitals; academic record and broad career choice were also related. ${ }^{9}$ The other report showed that undergraduate examination success was related to the possession of a higher qualification at a point four and a half years after graduation. ${ }^{10} \mathrm{~A}$ report from the United States found a generally low positive relation between measures of undergraduate performance and ratings in the first postgraduate year. ${ }^{11}$

In no report has the undergraduate examination performance of a representative student group been related to overall career success. Thus, in view of the paucity of evidence available, and particularly in the light of Hudson's general findings of poor 
relation between degree class and career, ${ }^{12}$ we decided to study the examination results of a cohort of entrants to the Cambridge University medical course and to relate these to subsequent career success.

\section{Subjects and method}

Clearly, a prime difficulty in such a study is in obtaining an index of career success: there can be no simple measure of this. We therefore compiled a list of indicators of success and selected the following: (a) possession of a higher medical degree-for example, MD; (b) possession of a specialist qualification (membership of the Royal College of Physicians (MRCP), fellowship of the Royal College of Surgeons (FRCS), etc); (c) the mention of publications in the Medical Directory; $(d)$ the award of fellowship of the Royal College of Physicians (FRCP) or equivalent; and $(e)$ a prestigious present appointment (at least equivalent to teaching hospital consultant or university senior lecturer).

These indicators are, of course, by no means perfect. Some may tend to be self fulfilling - for example, the possibility of registering for a higher degree could depend on an earlier degree classification-and their validity only partial. The final indicator (present appointment) ignores any differences in the general practitioner group, there being no convenient measure of the relative prestige of general practitioners. Taken together, however, they are an indication of career success.

To use these indicators it was necessary to study subjects who had started their training several years previously. Since medical education was seriously disrupted in and immediately after the second world war we decided to study the cohort of students entering the preclinical course at Cambridge University in the academic year 1950-1.

Of 222 medical students who matriculated in 1950-1, 188 subsequently received the Cambridge medical degree; most of the remainder received qualifying degrees from other universities. The tripos (equivalent to the preclinical degree examination) classifications were obtained for these 188 graduates as were the results of examinations for the final qualifying degree: both sets of data are publicly available. We then conducted a search in the 1982 editions of the Medical Directory and the Medical Register for up to date information on the 188 doctors. Satisfactorily complete information was obtained on 116 $(62 \%)$ doctors, with inadequate or non-existent data on the remainder -including, not unexpectedly, almost all the few women in the cohort (table I).

TABLE I-Cohort data for students entering medical school in 1950

\begin{tabular}{lcc}
\hline Total cohort & Total No & No of women \\
\hline Students matriculating 1950/51 & 222 & 13 \\
Students subsequently receiving Cambridge medical & 188 & 11 \\
degree & 116 & 1 \\
1981 search results of 188 graduates: & 10 & 2 \\
Graduates located: full information & 62 & 8 \\
Graduates located: information inadequate & & \\
Graduates not located &
\end{tabular}

As funds did not permit searches on 72 individuals by the registrar of the General Medical Council, we needed to determine whether the 116 located graduates were representative of the whole cohort. A comparison of the preclinical tripos classifications of both groups showed no important differences: similar results were found in a comparison of clinical examination results. We concluded that the 116 located graduates were representative in terms of the distribution of examination results of the total number of graduates. The virtual absence of women in this group-and indeed in the total entryshould, however, be noted. Data on the 116 graduates' qualifications and degrees, reported publications, and present (1981) appointment were then analysed in relation to undergraduate examination results.

\section{Results}

The relation between preclinical and clinical examination results for the 188 graduates was significant $(p<0 \cdot 01)$ but by no means complete (table II); an appreciable proportion of "firsts" and " $2.1 \mathrm{s"}$ " failed clinical examinations, and nearly $60 \%$ of "thirds" passed all of these at the first attempt.
TABLE II-Subjects' clinical examination results by preclinical degree classification (all graduates $n=188$ )

\begin{tabular}{ccc}
\hline Best tripos class & \% Of total & $\begin{array}{c}\text { \% Of graduates failing one or more clinical } \\
\text { examination }\end{array}$ \\
\hline 1 & 8 & 13 \\
2.1 & 16 & 13 \\
2.2 & 52 & 36 \\
3 & 23 & 42 \\
(Absent) & $(1)$ & $(100)$ \\
\hline
\end{tabular}

$\chi^{2}=10 \cdot 13, \mathrm{df}=2$ (combining cells), $\mathrm{p}<0 \cdot 01$. (All $\chi^{2}$ tests performed on actual numbers not percentages).

\section{PRECLINICAL TRIPOS CLASSIFICATION AND CAREER}

Table III shows the relation between preclinical degree classification and subsequent career. Again, in this group of 115 graduates there was a significant positive relation between tripos class and clinical examination success $(p<0.05)$. Positive relations were also found with possession of a higher degree $(p<0.05)$, a specialist qualification $(p<0.05)$, and with the award of FRCP or its equivalent $(p<0.02)$. Although differences in the proportions of subjects reporting publications and holding prestigious appointments were in the expected direction, they were not significant. Each of the five career indicators showed a positive relation with tripos class: if the indicators are considered as a sample randomly drawn from the total population of such, then this is a significant overall finding ( $p<0.05$, sign test).

Table IV shows a classification of present (1981) appointment by tripos class. No significant relation was apparent.

TABLE III-Preclinical tripos classification and subsequent career $(n=115$, one subject not classified)

\begin{tabular}{|c|c|c|c|c|c|c|}
\hline \multirow[b]{2}{*}{$\begin{array}{l}\text { Best tripos } \\
\text { class }\end{array}$} & \multirow[b]{2}{*}{$\begin{array}{l}\text { Failed } \\
\text { in } \\
\text { clinical } \\
\text { course } \\
(\%)\end{array}$} & \multicolumn{5}{|c|}{ Career success indicators: } \\
\hline & & $\begin{array}{c}\text { Higher } \\
\text { degree } \\
(\%)\end{array}$ & $\begin{array}{c}\text { Specialist } \\
\text { qualification } \\
\text { (MRCP/ } \\
\text { FRCS) } \\
(\%)\end{array}$ & $\begin{array}{c}\text { Reported } \\
\text { publications } \\
(\%)\end{array}$ & $\begin{array}{c}\text { FRCP or } \\
\text { equivalent } \\
(\%)\end{array}$ & $\begin{array}{l}\text { Prestigious } \\
\text { appointment } \\
(\%)\end{array}$ \\
\hline $\begin{array}{ll}1 & (n=12) \\
2.1 & (n=19) \\
2.2 & (n=57) \\
3 & (n=27)\end{array}$ & $\begin{array}{r}8 \\
21 \\
40 \\
37\end{array}$ & $\begin{array}{l}33 \\
32 \\
12 \\
15\end{array}$ & $\begin{array}{l}83 \\
79 \\
58 \\
41\end{array}$ & $\begin{array}{l}83 \\
63 \\
49 \\
41\end{array}$ & $\begin{array}{l}50 \\
47 \\
19 \\
19\end{array}$ & $\begin{array}{l}50 \\
32 \\
23 \\
19\end{array}$ \\
\hline $\begin{array}{l}\text { Significant } \\
\text { difference } \\
\left(\chi^{2} \text { test }\right)\end{array}$ & $\begin{array}{c}\text { Yes } \\
\text { df }=1 * \\
p<0.05\end{array}$ & $\begin{array}{c}\text { Yes } \\
\mathrm{df}=1 * \\
\mathrm{p}<0.05\end{array}$ & $\begin{array}{c}\text { Yes } \\
\mathrm{df}=\mathbf{3} \\
\mathrm{p}<\mathbf{0} \cdot 05\end{array}$ & No & $\begin{array}{c}\text { Yes } \\
\text { df }=3 \\
p<0.02\end{array}$ & No \\
\hline
\end{tabular}

*Combining cells.

TABLE IV-1981 Appointments by preclinical degree classification (actual numbers $n=115$, one subject not classified)

\begin{tabular}{cccccc}
\hline & \multicolumn{5}{c}{ Present appointment } \\
\cline { 2 - 6 } Best tripos & $\begin{array}{c}\text { Professor, } \\
\text { equivalent } \\
\text { or higher } \\
\text { status }\end{array}$ & $\begin{array}{c}\text { Teaching } \\
\text { hospital } \\
\text { consultant/ } \\
\text { senior } \\
\text { lecturer }\end{array}$ & $\begin{array}{c}\text { Other } \\
\text { hospital } \\
\text { consultant }\end{array}$ & $\begin{array}{c}\text { General } \\
\text { practitioner }\end{array}$ & $\begin{array}{c}\text { Other } \\
\text { post }\end{array}$ \\
\hline 1 & 2 & 6 & 3 & 2 & 1 \\
2.1 & 3 & 4 & 6 & 7 & 1 \\
2.2 & 1 & 10 & 23 & 21 & 14 \\
3 & 4 & 7 & 14 & \\
\hline
\end{tabular}

Differences not significant.

\section{CLINICAL EXAMINATION RESULTS AND CAREER}

The indicators of career success are contrasted in table $\mathrm{V}$ in terms of clinical examination success or otherwise. There were significant differences in the predicted direction in relation to possession of a specialist qualification $(\mathrm{p}<0.01)$, a prestigious present appointment $(p<0.02)$, and reported publications $(p<0.01)$. Differences in the proportions of those gaining a higher degree or holding an award (FRCP or equivalent) were not significant. All the five career indicators showed a positive relation with clinical examination success, however: with the same proviso as above, this was significant overall ( $p<0.05$ sign test).

Table VI shows a classification of present appointment by clinical 
examination result. The difference between the appointments of the two groups was highly significant $(p<0.001)$. This significant difference was due to the differences between general practitioners and hospital/university practitioners, however: there was no significant difference between the "levels" of the latter.

TABLE V-Clinical examination result and subsequent career $(n=116)$

\begin{tabular}{|c|c|c|c|c|c|}
\hline \multirow[b]{2}{*}{$\begin{array}{l}\text { Clinical examination } \\
\text { results }\end{array}$} & \multicolumn{5}{|c|}{ Career success indicators: } \\
\hline & $\begin{array}{c}\text { Higher } \\
\text { degree } \\
(\%)\end{array}$ & $\begin{array}{c}\text { Specialist } \\
\text { qualification } \\
\text { (MRCP or } \\
\text { FRCS) } \\
(\%)\end{array}$ & $\begin{array}{c}\text { Reported } \\
\text { publications } \\
(\%)\end{array}$ & $\begin{array}{c}\text { FRCP or } \\
\text { equivalent } \\
(\%)\end{array}$ & $\begin{array}{c}\text { Prestigious } \\
\text { appointment } \\
(\%)\end{array}$ \\
\hline $\begin{array}{l}\text { All passed at first } \\
\text { attempt }(n=77) \\
\text { One or more }\end{array}$ & 23 & 71 & 63 & 32 & 34 \\
\hline $\begin{array}{l}\text { examinations } \\
\text { failed }(n=39)\end{array}$ & 10 & 38 & 33 & 15 & 10 \\
\hline $\begin{array}{l}\text { Significant } \\
\text { difference } \\
\left(\chi^{2} \text { test }\right)\end{array}$ & No & $\begin{array}{c}\text { Yes } \\
\mathrm{df}=1 \\
\mathrm{p}<0.01\end{array}$ & $\begin{array}{c}\text { Yes } \\
\mathrm{df}=1 \\
\mathrm{p}<0.01\end{array}$ & No & $\begin{array}{c}\text { Yes } \\
\text { df }=1 \\
p<0.02\end{array}$ \\
\hline
\end{tabular}

TABLE VI-1981 Appointments by clinical examination result (actual numbers $n=116$ )

\begin{tabular}{lccccc}
\hline & \multicolumn{5}{c}{ Present appointment } \\
\cline { 2 - 6 } & $\begin{array}{c}\text { Teaching } \\
\text { Professor, } \\
\text { consital } \\
\text { clinical examination } \\
\text { sesults }\end{array}$ & $\begin{array}{c}\text { Other } \\
\text { highivalent or } \\
\text { higher status } \\
\text { lecturer }\end{array}$ & $\begin{array}{c}\text { hospital } \\
\text { consultant }\end{array}$ & $\begin{array}{c}\text { General } \\
\text { practitioner }\end{array}$ & $\begin{array}{c}\text { Other } \\
\text { post }\end{array}$ \\
\hline $\begin{array}{l}\text { All passed at first } \\
\text { attempt } \\
\begin{array}{c}\text { One or more } \\
\text { examination } \\
\text { failures }\end{array}\end{array}$ & 5 & 21 & 31 & 18 & 2 \\
\hline
\end{tabular}

$x^{2}=21 \cdot 1, d f=2($ combining cells),$p<0.001$.

\section{Discussion}

These results suggest that there is a general, positive, but quite tenuous relation between performance in undergraduate student examinations and subsequent career success. It is interesting that it was only the clinical examination results which had any significant relation with the present appointment (and this only with respect to the hospital doctor/general practitioner dichotomy). This suggests that only by the end of the clinical training are abilities relating to professional success measured with any reliability. (There is, incidentally, no support for a locally held view that " $2.1 \mathrm{~s}$ " do better than "firsts" in their subsequent careers.)

Nevertheless, the strength of the relation is low. Little can be predicted with any certainty for an individual from either tripos class or clinical examination results. For example, although many of the graduates who managed only a "third" in their tripos and who also failed in the clinical examinations do not hold prestigious appointments, several now hold senior positions: one is a consultant in a postgraduate teaching hospital. A significant relation does not necessarily allow confident predictions to be made.

Times change, of course, and what is regarded as success will change. Restrictions now make entry to general practice much harder, for example, and the career success indicators which might be selected for this year's intake might be different. Such developments may alter the picture, as might the advent of numbers of women graduates (who were effectively excluded from this study). Furthermore, the predictive value of undergraduate examinations may vary with career specialty. Further study of additional subsequent cohorts of graduates will be needed to establish this. The indicators used in this study are also open to improvement.

If this cohort of medical graduates is representative of others, then the results of this study have clear implications for selection at all stages of medical education. It confirms the poor relation between early academic success and subsequent career suggested by Hudson. ${ }^{12}$ The case has been made elsewhere for broadening the base of medical student selection-or returning to such a situation ${ }^{14}$-on theoretical, practical, and political grounds. ${ }^{15}$ The predictive value of $\mathrm{A}$ level grades has been shown to be almost nil even within the medical course. ${ }^{14}$ This study shows how slender the evidence may be for using measures of undergraduate academic success as principal evidence in making later decisions on selection, where this is done.

Unfortunately, degree classes and examination marks have an apparent precision which makes them attractive to selectors, but, as Professor Derek Rowntree commented, these may "encourage simplistic, prejudiced, and literally ill-formed expectations" of candidates. ${ }^{13}$ Indeed, he suggests that examination results should carry a kind of government health warning to the effect, "Relying too heavily on other people's opinions can damage your sense of reality." This is good advice, particularly if the opinions are of characteristics with no predictive validity.

Those responsible for selecting clinical students, junior doctors, and senior staff should be aware of these facts and seek as wide a variety of pertinent information as possible about applicants: research suggests that non-cognitive measures are likely to be especially helpful. ${ }^{76}$ Examination results must not be seen as reliable predictors of potential, but as inaccurate measures of past achievement.

RW is supported by the Marmaduke Sheild Trust.

\section{References}

${ }^{1}$ Fruen MA, Chipman M, Steiner JW. Attrition from general practice: career patterns of Toronto medical school graduates. F Med Educ 1977; $52: 494-9$.

2 Parkhouse J, Howard M. A follow-up of the career preferences of Manchester and Sheffield graduates of 1972 and 1973. Med Educ 1978;12: 377-81.

3 Egerton EA. Survey of Queen's University medical graduates. Ulster Med f 1980;49:112-25.

Dodd N. Follow-up study of male Liverpool graduates. Med Educ 1980 12:124-7.

5 Nadelson CC, Notman MT, Lowenstein P. A follow-up study of Harvard medical school graduates, 1967-1977. F Am Med Wom Assoc 1981;36: 51-62.

- Hobfoll SE, Benor DE. Prediction of student clinical performance. Med Educ $1981 ; 15: 231-6$.

7 Murden R, Galloway GM, Reid JC, Colwill JM. Academic and personal predictors of clinical success in a medical school. $\mathcal{F}$ Med Educ 1978;53: 711-9.

8 Wilson HD. A hundred years of the Ettles scholarship at the University of Edinburgh. Med Educ 1981;15:359-62.

- Last JM, Martin FM, Stanley GR. Academic record and subsequent career. Proc $R$ Soc Med 1967;60:813-6.

${ }^{10}$ Richardson IM. Examination performance and the future careers of Aberdeen medical graduates. Med Educ 1980;14:356-9.

11 Veloski J, Herman MW, Gonnella JA, Zeleznik C, Kellow WF. Relationships between performance in medical school and first postgraduate year. f Med Educ 1979;54:909-16.

${ }^{12}$ Hudson L. Selection and the problem of conformity. In: Meade JE, Parkes AS, eds. Genetic and environmental factors in human ability. Edinburgh: Oliver and Boyd, 1966:90-9.

${ }^{13}$ Rowntree D. Assessing students: how shall we know them? London: Harpe and Row, 1977.

14 McManus IC. A level grades and medical school admission. Br Med $1982 ; 284: 1654$.

15 Bennett MJ, Wakeford RE. Health policy, student selection and curriculum reform. Health Policy and Education 1982;3:173-81.

${ }^{16}$ Keck JE, Arnold L, Willoughby L, Calkins V. Efficacy of cognitive/noncognitive measures in predicting resident-physician performance. $\mathcal{F} \mathrm{Med}$ Educ 1979;54:759-65.

(Accepted 22 March 1983) 